\author{
Zaika S. O., Ph.D., Associate Professor \\ Kuskova S. V., Ph.D., Associate Professor \\ Zaika O. V., Assistant Lecturer \\ Kharkiv Petro Vasylenko \\ National Technical University of Agriculture \\ Kharkiv, Ukraine
}

DOI: https://doi.org/10.30525/978-9934-26-036-0-15

\title{
HUMAN CAPITAL AS THE FACTOR IN THE FORMATION OF THE KNOWLEDGE ECONOMY
}

One of the important components of the impact on people and society as a whole is the social system and its main component human capital. In recent years, the theory of human capital has become increasingly popular. The modern view of man as a carrier of human capital means the recognition of his abilities as capital, ie a value that brings income.

Many studies of both foreign and Ukrainian scientists $[2 ; 5 ; 8-11]$ are devoted to the study of human capital. However, despite the presence of a significant number of scientific papers on this topic $[1 ; 4 ; 6]$, the study of problems and prospects for human capital development is still relevant.

The formation of the knowledge economy began in the late twentieth century. Its characteristic difference was the accelerated development of the intangible sphere of economic activity of enterprises. At the same time, knowledge, rather than capital, increasingly became an economic resource that determined the competitiveness of enterprises.

Theories of human capital at the present stage will pay much attention, because it allows from a general standpoint to study many phenomena of market relations, to identify the effectiveness of financial resources invested in the human factor. The use of the concept of «human capital» allows us to understand the role of social institutions, to clarify not only the social parameters, but also to 
conduct an economic analysis of the impact of social factors on the market economy.

Modern economic development requires a rethinking of the existing theoretical foundations of the concept of human capital, necessitates the analysis of human capital in areas that reflect the specifics of using a set of creative abilities as assets of its capital.

The role of human capital in modern economic processes in contrast to traditional factors of production is growing, revealing changes in the current structure of human activity.

Today, the peculiarities of the process of acquiring and using knowledge determine a person's relationship with the enterprise, the intellectual capital of which it forms. Capital (knowledge) and means of production (intellectual tools of analysis, synthesis, modeling, etc.) determine the position of the employee as an internal entrepreneur. Depending on the method of use, there are usually two categories of knowledge:

1) knowledge in the form of information and without loss of content is transmitted through various media in the form of formulas, texts, symbols;

2) knowledge embodied in man and belong to him: abilities, innovative character traits $[1 ; 4-6]$.

The defining characteristic of human capital is its ability to create an additional product. As soon as it is excluded from the production process or used irrationally, extensively, it ceases to be a factor of production. The ability to generate income puts human capital on a par with other forms of capital that function in social production. It, like other types of capital, is characterized by a whole set of structural features:

- ability to self-growth;

- investment nature;

- participation in market exchange relations [3; 7].

Depending on the volume and regularity of investments in the development of human capital, the return from this factor of production increases, which is manifested both at the individual and 
social levels. For the carrier of labor, the high quality of human capital is expressed in higher rates of individual income.

At the level of social reproduction, the quality of human capital is manifested in the efficiency of production and economic growth (provided the full use of all other factors of production and their compliance with modern technical and technological requirements) [6]. Investments in human capital give the national economy the greatest income and ensure its growth, which makes them the most profitable forms of capital investment. The latter determine the susceptibility of society to new knowledge and technologies, intensify scientific and technical activities, and create motivation for development. It is these circumstances that reveal the unfoundedness of the idea that investment in people - is consumer spending, and prove their productive power $[3 ; 6]$.

Thus, knowledge, competence, professionalism of employees play an exceptional role in intensifying innovation, increasing competitiveness, market value and profitability of business and, consequently, in identifying new prospects for dynamic growth and economic development of the country. At the same time, effective human capital management provides a real opportunity to significantly increase the manageability, security, competitiveness, market value and profitability of the business, as well as opens new prospects for its dynamic growth and development.

\section{References:}

1. Edvinsson L. (2007) Intellectual Capital: Realizing Your Company's True Value by Finding Its Hidden Brainpower / L. Edvinsson, M.S. Malone. New York: HarperCollins Publishers. 240 p.

2. Fedulova L.I. (2008) Kontseptualni zasady ekonomiky znan [Conceptual foundations of the knowledge economy]. Ekonomichna teoriia, no. 2, pp. 37-59.

3. Mazniev H.Ye., Zaika S.O., Hridin O.V. (2016) Antykryzove upravlinnia yak sfera biznes-administruvannia [Crisis management as a field of business administration]. Scientific Bulletin of Uzhhorod National University. Series: "International Economic Relations and the World Economy», vol. 10, pp. 25-32.

4. Mincer J. (1958) Investment in Human capital and Personal Income Distribution. The Journal of Political Economy. 
5. Savitska S., Zaika S., Svystun L., Koval L., Haibura Y. (2020) Investment providing sustainable development of rural areas in Ukraine. Independent Journal of Management \& Production, vol. 11, no. 8, pp. 571-586. DOI: dx.doi.org/10.14807/ ijmp.v11i8.1218.

6. Schultz T. (1975) Human capital: Policy Issues and Research Opportunities. In Human Resources. Fiftieth Anniversary Colloquium VI.

7. Stewart T. (1999) Intellectual Capital - The New Wealth of Organizations. London: Nocholas Brealey Publishing House, $280 \mathrm{p}$.

8. Yakovenko L.I. (2010) Innovatsiinyi kharakter ekonomiky znan [The innovative nature of the knowledge economy]. Visnyk PDAA, no. 2, pp. 141-145.

9. Zadorozhnyi H.V., Kolupaieva I.V.(2009) Liudska diialnist: zmist i transformatsiia struktury u suchasnomu hospodarskomu rozvytku [Human activities: content and structure transformation in modern economic development]. Kharkiv: KhNU imeni V. N. Karazina, 158 p.

10. Zaika S., Gridin O. (2020) Human capital development in the agricultural economy sector. Technology audit and production reserves, no. 1/4(51), pp. 30-36.

11. Zaika S.O., Kuskova S.V., Zaika O.V. (2020) Problems of intellectual capital management in agricultural enterprises. Corporate Governance: Strategies, Processes, Technology: IV International scientific conference (October 23th, 2020. Leipzig, Germany). Riga, Latvia: "Publishing House "Baltija Publishing", pp. 61-63. 